\title{
TECHNIKY ZAJIŠTĚNí KOMODITNÍHO RIZIKA: PŘÍPAD DISTRIBUCE PLYNU
}

\author{
Denisa Vrebová, Markéta Jarotková
}

\section{Klíčová slova:}

Hedging, komoditní deriváty, zemní plyn, strategie zajištění.

\section{Keywords:}

Hedging, commodity derivatives, natural gas, hedging strategies.

\begin{abstract}
Abstrakt
Riziko lze chápat jako faktor nejistoty, že situace $\mathrm{v}$ budoucnu bude jiná, než plánovaná. $\mathrm{V}$ případě, který je studován v tomto článku, se jedná o cenu zemního plynu. Toto riziko je možné zajistit pomocí celé řady strategií. V článku jsou studovány a porovnány jen ty základní. Pomocí simulačního př́kladu je ukázáno, jaký může být dopad základních alternativ. Porovnání je provedeno pomocí kritérií pravděpodobnostního rozdělení efektu a krajních kvantilů. Dle teoretických očekávání je riziko minimální pro krytou pozici, zatímco bariérové opce znamenají jak nejvyšší střední hodnotu, tak riziko ve smyslu směrodatné odchylky.
\end{abstract}

\begin{abstract}
Risk can be understood as a lack of knowledge about future situations. In the case that is studied in this paper, it concerns the future price of a natural gas. This risk can be hedged by a broad family of strategies. In the paper we study and compare only the most standard strategies on the basis of a simulation study. Within the comparison we use the basic characteristics of probability distribution of the hedging effect and the quantiles of both tails. According to theoretical expectations, the risk is minimal for a covered position, whilst the barrier option means both the highest mean value and risk in sense of the standard deviation.
\end{abstract}

\section{Úvod}

Strukturální změny a nejistoty na finančních trzích nutí podniky ve finanční sféře i mimo ni efektivně řídit finanční rizika, nebot' jen takovým způsobem lze dosáhnout maximální efektivity při dosahování stanoveného strategického cíle, at' už jím je maximalizace tržní hodnoty nebo třeba maximalizace tržního podílu. Samozřejmě, v rámci zjednodušených předpokladů dokonalých trhů by efektivní řízení rizika prostřednictvím hedgingu nemělo být nijak bonifikováno, nicméně reálné trhy nejsou ideální, existují náklady bankrotu i získávání informací (blíže viz Tichý, 2009).

V rámci finančních trhů v širším slova smyslu lze dle skupin aktiv, s kterými se na nich obchoduje, rozlišit zejména trhy akciové, trhy s dluhovými cennými papíry, trhy s deriváty, trhy s měnami a v neposlední řadě i komoditní trhy. Trhy s komoditními zdroji jsou extrémně důležité pro zemědělský průmysl a činnosti s nimi související jako je výroba, zpracování a následná spotřeba. Neméně důležité jsou pro energetický průmysl a obdobná odvětví. Tyto trhy proto hrají velmi důležitou roli v ekonomickém rozvoji, mezinárodním obchodě, v celosvětové ekonomice a dokonce i politické stabilitě.

V současné době lze identifikovat dílčí trhy, na kterých se obchoduje s takovými druhy komodit, jako obilí, cukr, kakao, pomerančová št’áva, zviřrectvo, různé druhy kovủ, dále pak 
energie, po níž můžeme chápat ropu, benzín, topný olej, uhlí, zemní plyn a další. Právě na poslední zmiňovanou komoditu - zemní plyn - bude tento článek zaměřen.

Riziko lze chápat jako faktor nejistoty, že situace $\mathrm{v}$ budoucnu bude jiná, než plánovaná. V našem př́padě se tedy jedná o cenu zemního plynu, která je ovlivněna několika faktory. Prvním z nich je vývoj konkurenčních komodit, jako jsou topné oleje, černé uhlí a ropa na světových trzích. Právě ropa určuje vývoj ceny zemního plynu. Pokud dojde k cenovému propadu ropy, lze očekávat, že tato změna se v budoucnu promítne do cen zemního plynu. Druhým faktorem, který může negativně ovlivnit vývoj ceny plynu, je nepř́znivý vývoj měnových kurzů CZK/EUR či CZK/USD. Specialisté zabývající se řízením rizik se snaží udržet riziko na předem stanovené úrovni prostřednictvím vhodných technik a nástrojů, viz Overdahl a Kolb (2007) nebo Geman (2005).

Zajištění je v dnešní dynamické době nepostradatelnou záležitostí a kromě eliminace př́ípadných ztrát $\mathrm{z}$ faktorů, které nemáme možnost ovlivnit, dochází i k přesnějšímu finančnímu plánování. Tím samožrejmě $\mathrm{k}$ menším výkyvům v hospodářských výsledcích. To představuje i větší důvěru pro věřitele.

Cílem tohoto článku je porovnat některé základní strategie při zajištění ve společnosti zabývající se distribucí plynu. Postup článku je následující, nejprve dojde k definici základních vlastností derivátů a způsobů jejich oceňování. V navazující části budou objasněny základní hedgingové strategie. Ty budou následně aplikovány na reálném příkladu.

\section{Charakteristika derivátů}

Základním způsobem, jak se podnik může zajistit proti rizikům, je prostřednictvím využití finančních derivátů. Derivát lze definovat jako odvozený cenný papír, jehož hodnota závisí na ceně určitého podkladového aktiva. Takovým aktivem může být např́iklad akcie, burzovní index, úroková sazba, měnový kurz či cena komodity. Hlavním znakem derivátů je jejich termínový charakter. To znamená, že v současnosti dvě obchodní protistrany uzavřou mezi sebou obchod, $\mathrm{k}$ jehož vypořádání dojde $\mathrm{v}$ budoucnu. Při uzavírání tohoto obchodu je účastníky předem stanovena cena, za kterou pak v budoucnosti dojde k realizaci obchodu.

Obecně se rozlišují dvě hlavní skupiny derivátů. První jsou termínované kontrakty, spočívající $\mathrm{v}$ povinnosti obou účastníků kontraktu $\mathrm{v}$ době splatnosti derivátu vypořádat se dle podmínek uvedených ve smlouvě. Mezi tyto deriváty patří forwardy, futures či swapy. Druhou skupinou jsou opční kontrakty, nebo zjednodušeně opce, které dávají kupujícímu právo plnit a vypořádat kontrakt v době expirace dle podmínek ve smlouvě.

Deriváty je taktéž možné dělit podle druhu podkladového aktiva na komoditní, měnové, úrokové deriváty a deriváty na nákup a prodej cenných papírů. Dále bude pozornost zaměřena na komoditní deriváty, které se týkají nákupu nebo prodeje určitých fyzických komodit $\mathrm{v}$ budoucnosti a jsou založeny na principu výměny pevné částky $\mathrm{v}$ hotovosti za komoditní instrument (viz Hull, 2010 nebo Overdahl a Kolb, 2007).

Forwardy i futures jsou založeny na stejném principu, který spočívá v dohodě dvou stran o nákupu či prodeji určitého množství komodity za předem danou cenu k danému budoucímu datu. Hlavním rozdílem mezi těmito kontrakty je standardizace futures, která umožňuje jejich obchodovatelnost na organizovaných burzách, zatímco forwardy jsou přizpůsobeny na míru 
konkrétním subjektům a lze je obchodovat pouze na tzv. over the counter trzích (OTC) neboli přes přepážku. Tato odlišnost je příčinou větší likvidity a obchodovatelnosti furures.

U derivátů obecně, je důležité znát a umět rozlišit dlouhou a krátkou pozici. Držitel forwardu se nachází v dlouhé (long) pozici a je povinen koupit podkladové aktivum $S_{T}$, přičemž očekává růst jeho ceny. $\mathrm{V}$ případě, že tato cena vzroste nad realizační cenu $X$, realizuje zisk, $\mathrm{v}$ opačném případě ztrátu. Výstavce forwardu zaujímá krátkou (short) pozici a je povinen prodat podkladové aktivum $S_{T}$, přičemž předpokládá pokles jeho ceny. V př́ípadě, že tato cena poklesne pod realizační cenu $X$, realizuje zisk, v opačném případě ztrátu.

Opcí se rozumí podmíněný kontrakt, kdy kupující nebo prodávající má možnost volby zda opci využije či nikoli. Jedná se o smlouvu mezi dvěma stranami, že si během sjednané doby prodají či koupí určité množství podkladového aktiva za předem stanovenou realizační cenu. Hlavní výhodou opcí oproti termínovým kontraktům je ta, že umožňuje realizaci zisku $\mathrm{v}$ případě př́iznivého pohybu ceny podkladového aktiva.

Rozlišují se dva základní typy opcí, call opce (kupní), s kterou je spojeno právo držitele (nikoli povinnost) koupit podkladové aktivum za určitou cenu a v určitém čase, za které musí zaplatit opční prémii, tedy cenu opce. V př́ípadě, že majitel opci využije, je výstavce povinen dodat podkladové aktivum dle podmínek stanovených v kontraktu. U put opce (prodejní) má držitel právo prodat podkladové aktivum za určitou cenu a v určitém čase, za které musí zaplatit opční prémii. Výstavce opce má povinnost toto podkladové aktivum v daném čase a za sjednanou cenu koupit. S opcemi je možné obchodovat na burzách i na trhu OTC.

Stejně jako u forwardu jsou i zde rozlišovány dlouhé a krátké pozice. U opcí existují čtyři základní pozice a to dlouhá pozice v kupní opci (long call), krátká pozice v kupní opci (short call), dlouhá pozice v prodejní opci (long put) a krátká pozice v prodejní opci (short put). Jejich výplatní funkce vypadají postupně takto: long call opce, $V H=\max \left(S_{T}-X, 0\right)$, short call opce, $V H=\min \left(X-S_{T}, 0\right)$, long put opce, $V H=\max \left(X-S_{T}, 0\right)$, a short put opce, $V H=\min \left(S_{T}-X, 0\right)$.

Opce se na trhu vyskytují v několika modifikacích. Pokud je možné opci využít pouze v době realizace, tedy v čase $T$, jedná se o evropskou opci. V prrípadě, že může dojít k její výplatě kdykoliv do doby zralosti, tedy v čase [0,T], hovoříme o americké opci a jako bermudská je opce označována, pokud je možné ji využít v konečném počtu okamžiků po dobu životnosti.

Dále je možné členit opce dle složitosti výplatní funkce na plain vanilla opce, neboli jednoduché opce a exotické opce s komplikovanější výplatní funkcí.

Hodnotu plain vanilla put $p$ a call opce $c$ lze stanovit pomocí Blackova-Scholesova modelu upraveného na komodity:

$$
\begin{gathered}
c=\left(S_{0}+U\right) \cdot e^{-c y \cdot T} \cdot N\left(d_{1}\right)-X \cdot e^{-r_{f} \cdot T} \cdot N\left(d_{2}\right), \\
p=X \cdot e^{-r_{f} \cdot T} \cdot N\left(-d_{2}\right)-\left(S_{0}+U\right) \cdot e^{-c y \cdot T} \cdot N\left(-d_{1}\right) .
\end{gathered}
$$

$S_{0}$ je hodnota komodity v době uzavření kontraktu v čase $t_{0}, X$ vyjadřuje realizační cenu, $N\left(d_{1}\right)$ a $N\left(d_{2}\right)$ vyjadřuje hodnotu funkce kumulativního normovaného normálního rozdělení, $e^{-r_{f} \cdot T}$ je spojitý diskontní faktor a $r_{f}$ je bezriziková sazba. U komodit musíme uvažovat i se skladovacími náklady $U$ a přínosy z držení komodity spotřební povahy $c y$. 
Opce mohou mít podobu i tzv. bariérových opcí, jejichž výplata závisí na tom, zda v době životnosti $T$ cena podkladového aktiva překročí určitou bariéru a dojde k aktivaci opce (knock-in opce) nebo k jejímu zrušení (knock-out opce).

Pokud by došlo k proražení stanovené hranice zdola, mluvíme o up-and-in nebo up-and-out opci, v opačném případě, když dojde k proražení hranice shora, jedná se o down-and-in nebo down-and-out opci. S tím souvisí existence horní $H^{u}$ a dolní $H^{d}$ bariéry. Mezi výhody těchto opcí se řadí jejich nižší cena než u srovnatelných evropských nebo amerických opcí. Z tohoto důvodu se staly tyto opce oblíbeným pojistným nástrojem.

Výplatní funkce bariérových opcí jsou následující:

$$
\begin{aligned}
& V H^{\text {knock-in }}=V H^{\text {call }} \text { pokud }\left\{\begin{array}{l}
S_{T}>H^{u} \\
S_{T}<H^{d}
\end{array}\right\} \text { jinak } V H^{\text {knock-in }}=0, \\
& V H^{\text {knock-out }}=0 \text { pokud }\left\{\begin{array}{l}
S_{T}>H^{u} \\
S_{T}<H^{d}
\end{array}\right\} \text { jinak } V H^{\text {knock-out }}=V H^{\text {call }} .
\end{aligned}
$$

Při určování ceny down-and-in a down-and-out call opce může nastat několik situací. Pokud bariéra $H$ je menší nebo rovná realizační ceně $X$, tak hodnota down-and-in call opce je vyjádřena pomocí tohoto vztahu,

$$
c_{d i}=\left(S_{0}+U\right) \cdot e^{-c y \cdot T} \cdot\left(\frac{H}{S_{0}+U}\right)^{2 \cdot \lambda} \cdot N(y)-X \cdot e^{-r_{f} \cdot T}\left(\frac{H}{S_{0}+U}\right)^{2 \cdot \lambda-2} \cdot N(y-\sigma \sqrt{T}) .
$$

Součet hodnot down-and-in call opce a down-and-out call opce se rovná hodnotě call opce, potom hodnotu down-and-out call opce lze vyjádřit $c_{d o}=c-c_{d i}$.

Ostatní vztahy pro určení cen down-and-in call opce a down-and-out call opce při $H \geq X$ a cen up-and-in a up-and-out call opce při $H \geq X$ a $H \leq X$ jsou detailně popsány v publikaci Hauga (2006), další detaily lze případně nalézt i v Haug (2007).

\section{Přístupy k zajištění komoditního rizika}

Hlavní příčinou vzniku finančních derivátů byla snaha zajistit se proti finančním rizikům. Finanční deriváty mají podstatný význam pro řízení rizik a využívají se především k hedgingu, který slouží k zajištění proti nepříznivému vývoji ceny aktiv. Touto oblastí se zabývali např́íklad Zmeškal (2004) nebo Tichý (2009), přičemž mnohé ilustrující př́́klady lze nalézt v Zmeškal a kol. (2011).

Princip hedgingu spočívá ve vytvoření hedgingového portfolia z rizikových aktiv, které chceme zajistit a finančních derivátů. Cílem je vytvořit takové hedgingové portfolio, aby jeho riziko bylo menší než riziko původního podkladového aktiva (viz Zmeškal, 2004). Za tímto účelem lze využít celou řadu metod - proto budou v následující části popsány pouze ty, které budou následně aplikovány a srovnány.

\subsection{Zajištění forwardem}

Při sestavení bezrizikového portfolia za pomocí forwardu musí být splněna podmínka nemožnosti arbitráže, tzn., že portfolio musí mít bezrizikový výnos. Portfolio lze sestavit následovně:

$$
\Pi=S-F \text { př́ípadně } \Pi=-S+F \text {. }
$$

Sestavené portfolio je skutečně bezrizikové, pokud známe hodnotu forwardu v době realizace, a tedy $\Pi_{T}=X$ pro jakoukoliv hodnotu finančního instrumentu: 


$$
t=T: \quad \Pi_{T}=S_{t} \cdot e^{-d \cdot \tau} \cdot e^{(\mu+d) \cdot \tau}-\left(S_{t} \cdot e^{\mu \cdot \tau}-X\right)=X .
$$

Současnou hodnotu získáme pomocí diskontování bezrizikovou sazbou $r$ a po úpravě platí:

$$
F_{t, T}=S_{t} \cdot e^{-d \cdot \tau}-X \cdot e^{-r \cdot \tau} .
$$

Kde $d$ představuje dodatečný výnos. Dodatečným výnosem rozumíme dividendový výnos, př́nosy z fyzického držení a skladovací náklady, které snižují dodatečný výnos. V následující Tabulce 1 je zachycena výplata forwardu na komoditu a sestavení bezrizikového portfolia.

Tabulka 1 Výplata forwardu na komoditu a bezrizikové portfolio

\begin{tabular}{|c|c|c|c|c|c|}
\hline $\begin{array}{c}\text { Stav/ } \\
\text { Pozice }\end{array}$ & $\begin{array}{c}\text { Nákup } \\
\text { aktiva S }\end{array}$ & $\begin{array}{c}\text { Prodej } \\
\text { aktiva S }\end{array}$ & $\begin{array}{c}\text { Dlouhá } \\
\text { pozice }\end{array}$ & $\begin{array}{c}\text { Krátká } \\
\text { pozice }\end{array}$ & $\begin{array}{c}\text { Bezrizikové } \\
\text { portfolio }\end{array}$ \\
\hline & $S_{T}$ & $-S_{T}$ & $F_{T}$ & $-F_{T}$ & $\Pi_{T}=S_{T}-F_{T}$ \\
\hline 320 & +314 & -314 & -36 & 36 & $314+36=350$ \\
\hline 335 & +328 & -328 & -22 & 22 & $328+22=350$ \\
\hline 350 & +343 & -343 & -7 & 7 & $343+7=350$ \\
\hline 365 & +358 & -358 & 8 & -8 & $358-8=350$ \\
\hline 380 & +372 & -372 & 22 & -22 & $372-22=350$ \\
\hline
\end{tabular}

Symbol $S_{T}$ označuje cenu komodity pohybující se v době zralosti v rozmezí [320;380] s intervalem $\Delta S=15 \mathrm{Kč}$, bezriziková sazba $r_{f}$ je ve výši $1,5 \%$ a realizační cena $X=350$ Kč. Cena podkladového aktiva v době zralosti $S_{T}$ je snížena o skladovací náklady, které činí $2 \%$.

\subsection{Call opce}

U opcí má podstatný význam vnitřní hodnota. Je definována jako přínos z okamžitého uplatnění opce a odpovídá výplatní funkci. Jinými slovy lze říci, jestliže se uskuteční nákup resp. prodej podkladového aktiva na derivátovém trhu a následný nákup resp. prodej stejného aktiva na promptním trhu dostaneme rozdíl mezi výnosem na derivátovém trhu a náklady na trhu promptním. Výše tohoto rozdílu odpovídá vnitřní hodnotě opce.

Výplatní funkce call opce na komoditu je znázorněna v Tabulce 2. Portfolio se vypočte dle následujícího vztahu,

$$
\Pi=S-c \quad \text { př́padně } \quad \Pi=-S+c .
$$

Tabulka 2 Výplata call opce a portfolio

\begin{tabular}{|c|c|c|c|c|c|c|}
\hline $\begin{array}{c}\text { Stav/ } \\
\text { Pozice }\end{array}$ & $\begin{array}{c}\text { Nákup } \\
\text { aktiva S }\end{array}$ & $\begin{array}{c}\text { Prodej } \\
\text { aktiva S }\end{array}$ & $\begin{array}{c}\text { Dlouhá } \\
\text { pozice }\end{array}$ & $\begin{array}{c}\text { Krátká } \\
\text { pozice }\end{array}$ & \multicolumn{2}{|c|}{ Portfolio } \\
\hline & $S_{T}$ & $-S_{T}$ & $c_{T}$ & $-c_{T}$ & $\Pi_{T}=S_{T}-c_{T}$ & $\Pi_{T}=-S_{T+} c_{T}$ \\
\hline 320 & +314 & -314 & 0 & 0 & $314-0=314$ & $-314+0=-314$ \\
\hline 335 & +328 & -328 & 0 & 0 & $328-0=328$ & $-328+0=-328$ \\
\hline 350 & +343 & -343 & 0 & 0 & $343-0=343$ & $-343+0=-343$ \\
\hline 365 & +358 & -358 & 8 & -8 & $358-8=350$ & $-358+8=-350$ \\
\hline 380 & +372 & -372 & 22 & -22 & $372-22=350$ & $-372+22=-350$ \\
\hline
\end{tabular}

Výplatní funkce knock out a knock in put opcí se vyvíjí stejně jako plain vanilla put opce, do okamžiku než cena podkladového aktive $S_{T}$ dosáhne stanovené bariéry $H^{u}$ nebo $H^{d}$.

\subsection{Pasivní strategie}

Pasivní strategie, jinak také nezajištěné portfolio, spočívá v tom, že firma uzavře kontrakt na dodání určité komodity, za které má inkasovat v budoucnu peníze. Vzhledem k tomu, že na cenu této komodity mohou mít vliv jak úrokové sazby, měnový kurz či cena jiné komodity a 
další kritéria, tak odběrateli vzniká riziko z nepříznivého vývoje ceny tohoto aktiva. Pokud se odběratel proti výkyvům ceny nezajistí, nachází se v tzv. nekryté pozici a je držitelem nezajištěného portfolia. Pokud firma nakoupí v čase $t_{0}$ požadované množství komodity na celé období za cenu $S_{t}$, bude se nacházet v tzv. kryté pozici.

\section{Porovnání vybraných metod zajištění komoditního rizika}

V této části článku budou vybrané hedgingové strategie aplikovány a porovnány na případu plynárenské společnosti, která se zabývá distribucí plynu. Trh s plynem je velmi dynamický a výkyvy cen jsou těžko předvídatelné a snadno ovlivnitelné různými faktory, jako jsou úroky, měny, ceny jiných komodit, $v$ našem případě cena ropy, která přímo úměrně ovlivňuje cenu plynu. $Z$ těchto důvodů se společnost rozhodne zajistit proti komoditnímu riziku plynoucímu z růstu ceny plynu. Aby společnost uspokojila poptávku svých zákazníků, má v plánu měsíčně nakupovat 480000 MWh plynu (tj. 5760000 MWh/za rok).

Úrokové sazby jsou pro zjednodušení určeny na bázi sazeb mezibankovního trhu PRIBOR. Denní úroková sazba činí $1,03 \%$, týdenní je ve výši 1,12 \%, měsíční na úrovni 1,23\% a roční se pohybuje na úrovni $1,95 \%$, vše v ročním vyjádření.

Za účelem ověření a posouzení jednotlivých metod je třeba nejprve namodelovat budoucí vývoj rizikového faktoru - ceny plynu. Náhodný proces, který je cenou plynu sledován, může obecně sledovat celou řadu stochastických procesů, jako jsou Mean reversion procesy zohledňující návrat $\mathrm{k}$ dlouhodobé rovnováze nebo geometrický Brownův proces $\mathrm{s}$ logaritmickými cenami. V případě mean reversion procesů se může dále jednat o OrnsteinUhlenbeckův model s aritmetickými cenami, Ornstein-Uhlenbeckův model s logaritmickými cenami a Schwartzův model. ${ }^{1}$ Nicméně pro dostupná data za předchozích osm let nebyl prokázán žádný statisticky významný trend návratu k rovnováze a tak je pro modelování budoucích cen využito (geometrického) Brownova procesu na bázi normálního rozdělení. Pro ověření jednotlivých strategií budeme předpokládat 50000 scénářů náhodného vývoje (viz Tichý, 2010).

Výsledný efekt ze zajištění bude stanoven na bázi vynaložených nákladů na nákup daného objemu plynu. Celkový efekt bude přepočítán pomocí úročitele ke konci roku. Jednotlivé efekty budou vyjádřeny $\mathrm{v}$ čase $T=252$. Vstupní parametry, které poslouží pro zjištění celkového efektu ze zajištění, jsou počáteční kurz $S_{0}=348,5 \mathrm{Kč} / \mathrm{MWh}$, realizační cena $X=$ $346 \mathrm{Kč} / \mathrm{MWh}$, roční bezriziková sazba $r_{f}=1,95 \%$, doba do splatnosti $T=1$ rok, denní objem nakupované komodity $q=16000 \mathrm{MWh}$, týdenní objem nakupované komodity $q=80000$ MWh, měsíční objem nakupované komodity $q=480000$ MWh.

\subsection{Krytá pozice}

Kdyby společnost zamýšlela nakoupit $\mathrm{v}$ čase $t_{0}$ požadovaný objem plynu, musela by mít $\mathrm{k}$ dispozici jednak dostatek kapitálu na nákup tohoto objemu, jednak by musela počítat se vzniklými náklady na jeho skladování. Celkové skladovací náklady $U$ lze vyjádřit takto,

\footnotetext{
${ }^{1}$ Kromě publikací Hull $(2010)$ a Haug $(2006,2007)$, Ize tyto i mnohé další kandidáty pro modelování cen komodit nalézt v Blanco a Soronow (2001), Geman (2005), Schofield (2007) nebo Schaeffer (2008).
} 


$$
U=\frac{N_{s} \cdot q}{2}
$$

kde $N_{s}$ představuje průměrné náklady na skladování jedné jednotky za určité období, $q$ je velikost objemu plynu v hmotných jednotkách (v MWh).

Výsledný efekt se rovná celkovému objemu plynu na rok (tj. 5760000 MWh), vynásobený aktuální spotovou cenou $S_{t}$, zúročený bezrizikovou sazbou. K tomuto součtu jsou přičteny celkové roční skladovací náklady. Efekt z nákupu komodity se propočte pomocí vztahu,

$$
E=q \cdot S_{t} \cdot e^{r_{f}\left(t_{i}-t\right)}+\sum_{t_{i}} U_{t_{i}} \cdot e^{-r_{f}\left(t_{i}-t\right)}=3654891 \text { tis.Ǩ̌ } .
$$

Skladovací náklady $\sum_{t_{i}} U_{t_{i}} \cdot e^{-r_{f}\left(t_{i}-t\right)}$ na rok představují sumu za jednotlivé dny do doby vyčerpání zásob. Společnost na nákup daného objemu plynu potřebuje 3654891 tis. Kč.

\subsection{Pasivní strategie}

Pasivní strategie spočívá $\mathrm{v}$ tom, že společnost neprovádí žádné úkony, kterými by se snažila riziko částečně snížit nebo zcela eliminovat. Společnost zvažuje nákup požadované kapacity na začátku každého týdne $\mathrm{v}$ čase $t_{i}(i=1,2, \ldots 52)$. Během tohoto týdne firma neprovádí žádné zajištovací kroky proti pohybu ceny plynu. Opět firma musí mít dostatek peněžních prostředků na nákup daného objemu.

Efekt $\mathrm{z}$ této pozice se vypočte jako suma nákladů za jednotlivé týdny zúročené bezrizikovou sazbou, ke kterým jsou přičteny náklady na skladování za jednotlivé týdny.

Celkový efekt je na úrovni vynaložených nákladů na pořízení komodity za celý rok:

$$
E=\sum_{t_{i}}\left(q^{t} \cdot S_{t_{i}} \cdot e^{r_{f}\left(t_{i}-t\right)}+U_{t_{i}} \cdot e^{-r_{f}\left(t_{i}-t\right)}\right),
$$

$U_{t_{i}}$ představuje skladovací náklady na jeden týden. Cena za $1 \mathrm{MWh}$ je rovna $S_{t_{i}}\left(S_{1}, S_{2}, \ldots\right.$ $S_{52}$ ), za kterou se nakupuje na začátku týdne daný objem plynu. Rozdělení pravděpodobnosti z týdenní pasivní strategie je zobrazen pomocí Obrázku 1.

Jestliže by se společnost rozhodla nakoupit daný objem plynu na začátku každého měsíce tedy $\mathrm{v}$ čase $t_{i}(i=1,2, \ldots 12)$ dostane se do tzv. nekryté pozice. Vystavuje se potenciálním rizikům v podobě znehodnocení měny či růstu ceny komodity. Společnost musí disponovat s určitým množstvím peněz na nákup plynu.

Celkový efekt bude odpovídat výši nákladů, za které byl daný objem plynu nakoupen:

$$
E=\sum_{t_{i}}\left(q^{m} \cdot S_{t_{i}} \cdot e^{r_{f}\left(t_{i}-t\right)}+U_{t_{i}} \cdot e^{-r_{f}\left(t_{i}-t\right)}\right),
$$

Celkový efekt za jednotlivé měsíce lze získat:

$$
E=\sum_{t_{i}}\left(q^{m} \cdot S_{t_{i}} \cdot e^{r_{f}\left(t_{i}-t\right)}+U_{t_{i}} \cdot e^{-r_{f}\left(t_{i}-t\right)}\right) .
$$

Měsíční skladovací náklady jsou variabilní podle počtu dní v měsíci a pohybují se v rozmezí $[19,96 ; 20,63]$. Cena za $1 \mathrm{MWh}$ odpovídá ceně na začátku každého měsíce $S_{t_{i}}=S_{1}, S_{2}, \ldots S_{12}$. Efekt z této zajišt'ovací strategie je zobrazen pomocí Obrázku 2. 
Obrázek 1 Efekt z týdenní nezajištěné pozice

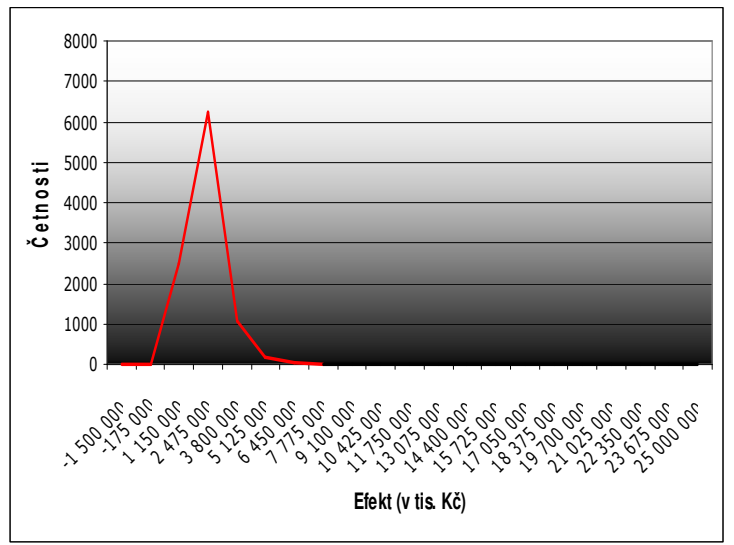

Obrázek 2 Efekt z měsíční nezajištěné pozice

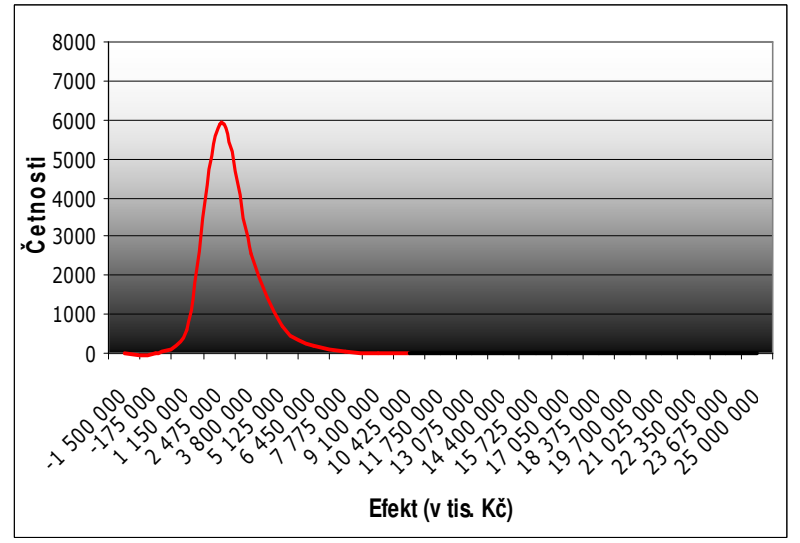

\subsection{Forwardový kontrakt}

Společnost má také možnost využít forwardový kontrakt, u kterého bude docházet ke každodennímu vypořádání, tj. $t_{i}(i=1,2, \ldots 252)$. Denní fixovaná částka je ve výši 346 $\mathrm{Kč} / \mathrm{MWh}$, př́nosy z držení komodity $c y=3 \%$ a doba do splatnosti $(T-t)=1$ rok. Tímto způsobem společnost každý den nakoupí daný objem za dohodnutou realizační cenu.

Celkový efekt se určí na základě rozdílu mezi náklady na pořízení daného objemu a částkou, kterou společnost denně uhradí za sjednaný objem vynásobený danou kapacitou:

$$
E=\sum_{t_{i}}\left(q^{d} \cdot S_{t_{i}} \cdot e^{r_{f} \cdot\left(t_{i}-t\right)}+U_{t_{i}} \cdot e^{-r_{f} \cdot\left(t_{i}-t\right)}\right)-\sum_{t_{i}} q^{d} \cdot X \cdot e^{r_{f} \cdot\left(t_{i}-t\right)},
$$

kde $S_{t_{i}}$ je aktuální cena plynu v čase $t_{i}(i=1,2, \ldots 252)$. Skladovací náklady $U$ na den činí 0,7 Kč/MWh. Výsledky z tohoto zajištění jsou zřejmé z Obrázku 3.

\subsection{Call opce}

Společnost také zvažuje, že v čase $t_{0}$ nakoupí call opce na rok dopředu, přičemž k vypořádání bude docházet každý den tj. $t_{i}(i=1,2,3, \ldots$ 252). Jedna tato opce zní na 1000 MWh a její hodnota byla vyčíslena na $c=112354$ Kč.

Tento způsob zajištění zahrnuje $\mathrm{v}$ sobě výhodu v podobě možnosti odstoupení od smlouvy. Společnost stojí v dlouhé pozici, kdy má možnost volby zda opci využije či nikoliv. Za právo volby vzniká firmě ztráta ve výši opční prémie $c$, kterou musí zaplatit protistraně. Má možnost koupit komoditu za nižší cenu než je stanoveno ve smlouvě, v našem prrípadě za cenu nižší než je realizační cena $X=346$ Kč/MWh.

Opce bude využita $\mathrm{v}$ případě, že cena komodity bude větší než realizační cena $S_{t_{i}}>X, \mathrm{v}$ opačném př́ípadě nedojde k uplatnění opce.

Výsledný efekt z této pozice je:

$$
E=\sum_{t_{i}}\left[\left(q \cdot S_{t_{i}} \cdot e^{r_{f} \cdot\left(t_{i}-t\right)}+U_{t_{i}} \cdot e^{-r_{f} \cdot\left(t_{i}-t\right)}\right)-V H_{t_{t}}^{c} \cdot 1000 \cdot q+c \cdot q \cdot e^{r_{f} \cdot\left(t_{i}-t\right)}\right],
$$

kde $\left(q \cdot S_{t_{i}} \cdot e^{r_{f} \cdot\left(t_{i}-t\right)}+U_{t_{i}} \cdot e^{-r_{f} \cdot\left(t_{i}-t\right)}\right)$ představuje prostředky na nákup plynu včetně skladovacích nákladů, $V H_{t_{i}}^{c} \cdot 1000 \cdot q$ je cash flow z call opce za jednotlivé dny a $c \cdot q \cdot e^{r_{f} \cdot\left(t_{i}-t\right)}$ jsou náklady na nákup opcí. Výsledky z této pozice jsou uvedeny v Obrázku 3. 
Obrázek 3 Rozdělení pravděpodobnosti z forwardu (vlevo) a call opce (vpravo)
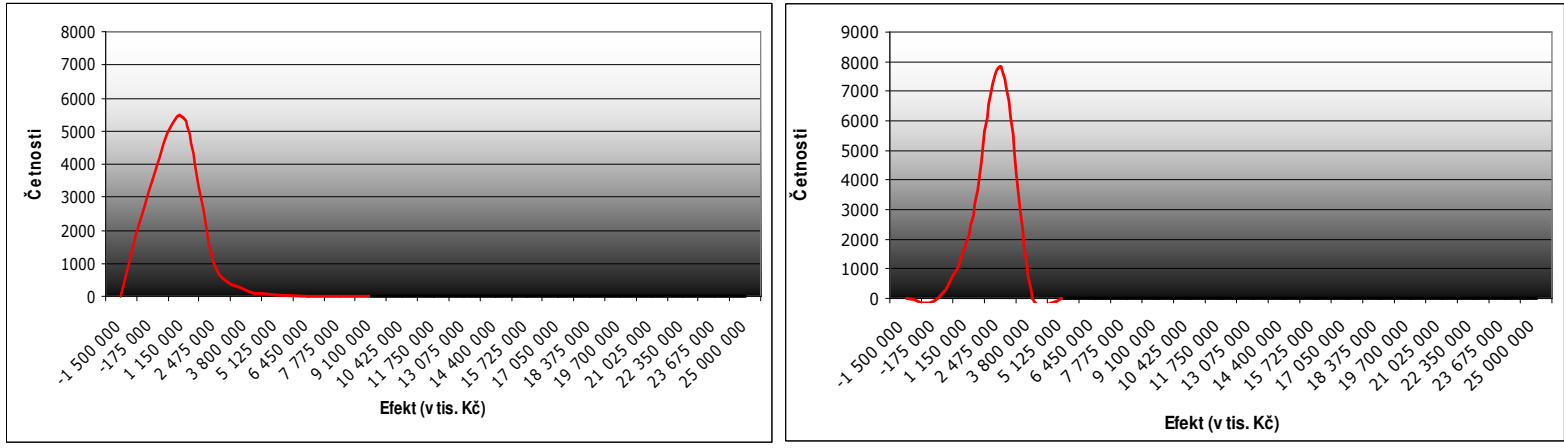

\subsection{Bariérové opce}

Společnost může $\mathrm{v}$ čase $t_{0}$ také nakoupit bariérové opce na rok dopředu. K vypřádání bude docházet každý den tj. $t_{i}(i=1,2,3, \ldots$ 252). Opět bereme v úvahu, že jedna opce zní na 1000 MWh.

U bariérových opcí je postup obdobný jako u předešlých dvou opcí. Rozdíl spočívá v tom, že jejich vnitřní hodnota je závislá na tom, zda cena komodity dosáhne v průběhu životnosti opce stanovené hranice. V našem případě je horní bariéra $H^{u}$ ve výši $350 \mathrm{Kč/MWh}$, která leží výše než realizační cena a dolní bariéra $H^{d}$ je ve výši 340 Kč/MWh ležící na nižší úrovni než realizační cena. Pokud bude bariéra dosažena, dojde k aktivaci opce tzv. knock-in, v opačném př́ípadě dojde k jejímu zrušení tzv. knock-out.

Efekt ze zajištění je,

$$
E=\sum_{t_{i}}\left[\left(q \cdot S_{t_{i}} \cdot e^{r_{f} \cdot\left(t_{i}-t\right)}+U_{t_{i}} \cdot e^{-r_{f} \cdot\left(t_{i}-t\right)}\right)-V H_{t_{t}}^{\text {call-bariérováa }} \cdot 1000 \cdot q+c_{\text {bariérováa }}^{\text {call }} \cdot q \cdot e^{r_{f} \cdot\left(t_{i}-t\right)} .\right.
$$

$\mathrm{V}$ době zralosti jsou jednotlivé náklady na nákup opce na úrovni $c_{d i}=80382 \mathrm{Kč}, c_{d o}=$

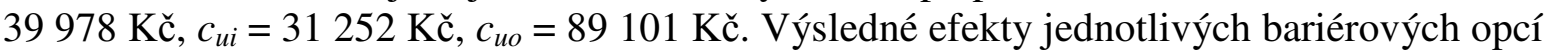
jsou znázorněny v Obrázcích 4 a 5.

Obrázek 4 Efekt z down-and-in call opce (vlevo) a down-and-out call opce (vpravo)
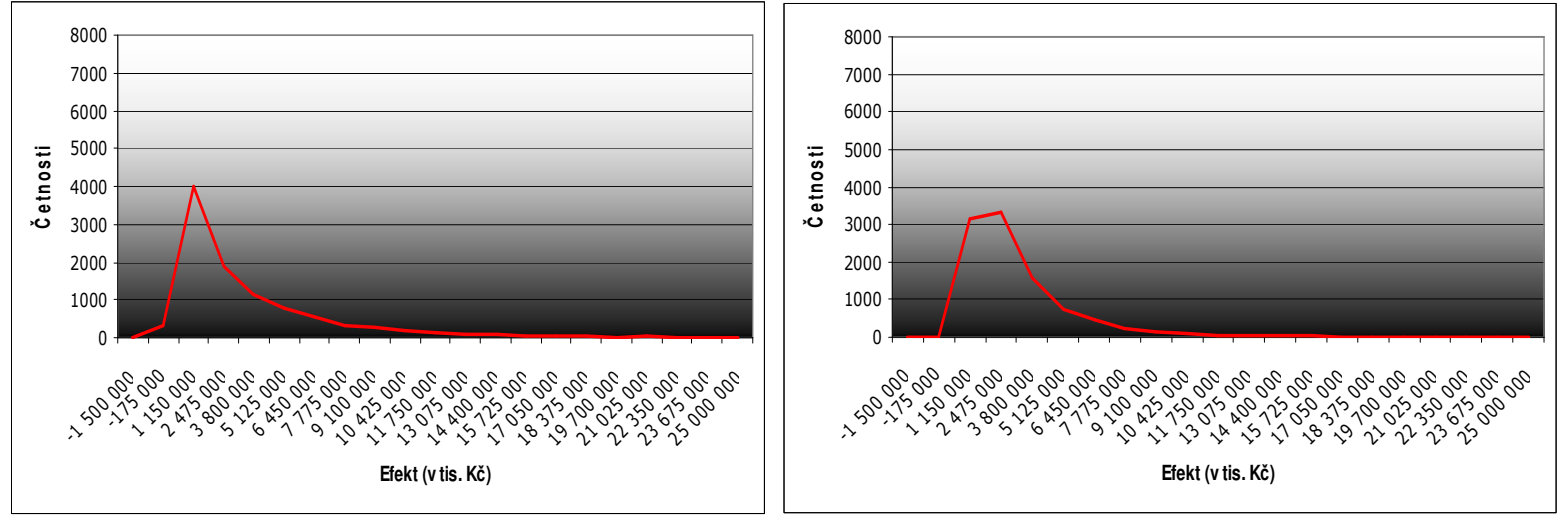
Obrázek 5 Efekt z up-and-in call opce (vlevo) a up-and-out call opce (vpravo)
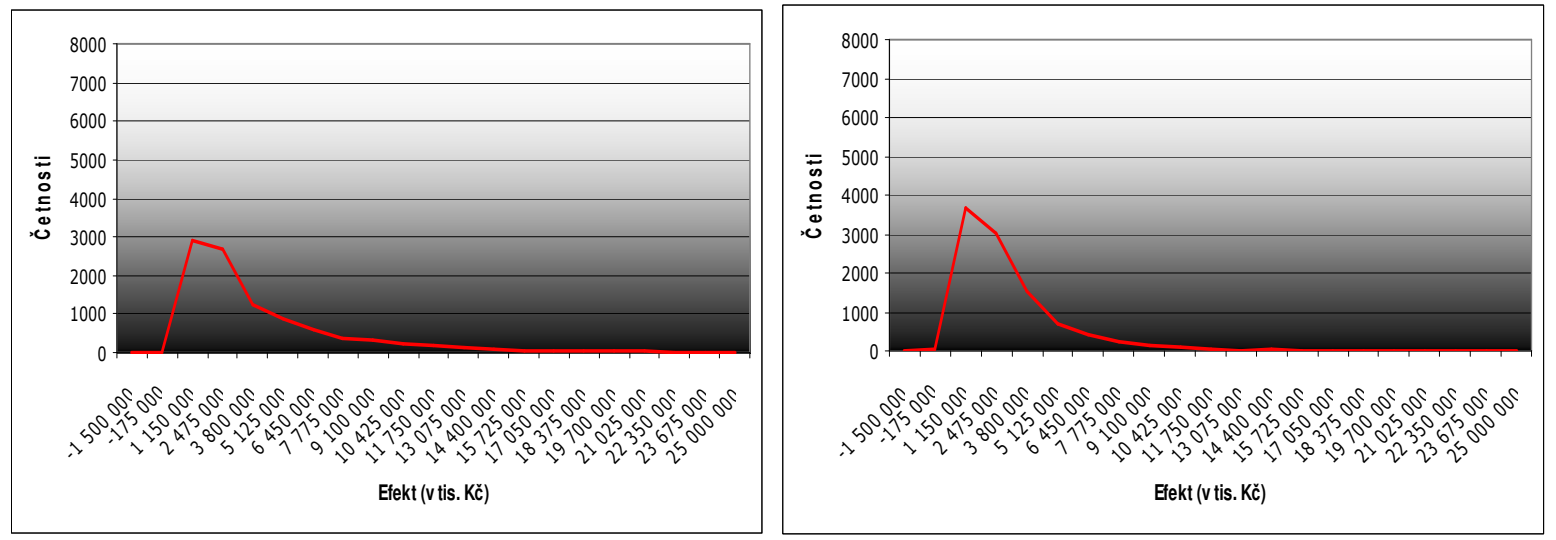

\section{Zhodnocení hedgingových strategií}

Vybrané strategie budou zhodnoceny na základě kritérií střední hodnoty, směrodatné odchylky, mediánu, šikmosti, špičatosti, VaR 10\% a VaR 90\%. Rozhodovacím kritériem pro výběr nejvhodnějšího modelu bude směrodatná odchylka. Tato kritéria budou porovnána mezi vybranými strategiemi. Poté budou dané strategie zhodnoceny jak dle vztahu výnos - riziko, tak $\mathrm{z}$ hlediska jejich vhodnosti pro subjekty s různým vztahem k riziku. Výsledné hodnoty stanovených kritérií pro vybrané strategie jsou zobrazeny v Tabulce 3. Nejúspěšnější strategie $\mathrm{v}$ rámci každého kritéria je zvýrazněna tučně.

Tabulka 3 Porovnání jednotlivých kritérií

\begin{tabular}{|c|c|c|c|c|c|c|c|c|}
\hline \multirow{2}{*}{\multicolumn{2}{|c|}{$\begin{array}{c}\text { Kritérium } \\
\text { Strategie }\end{array}$}} & \multirow{2}{*}{$\begin{array}{l}\text { Střední } \\
\text { hodnota }\end{array}$} & \multirow{2}{*}{$\begin{array}{l}\text { Směrodat. } \\
\text { odchylka }\end{array}$} & \multirow{2}{*}{ Medián } & \multirow{2}{*}{ Šikmost } & \multirow{2}{*}{ Špičatost } & \multirow{2}{*}{$\begin{array}{l}\text { VaR } \\
10 \%\end{array}$} & \multirow{2}{*}{$\begin{array}{l}\text { VaR } \\
90 \%\end{array}$} \\
\hline & & & & & & & & \\
\hline \multicolumn{2}{|c|}{ Krytá pozice } & 3654891 & $\mathbf{0}$ & 3654891 & 0 & 0 & 0 & 0 \\
\hline \multirow{2}{*}{ Pasivní } & Týdenní & 2281679 & 779554 & 2847477 & 1,83 & 6,49 & 471955 & 602306 \\
\hline & Měsíční & 3257693 & 1121534 & 3479424 & 2,00 & 7,46 & 683018 & 864960 \\
\hline \multicolumn{2}{|c|}{ Forwardový kontrakt } & 1098543 & 947414 & 1547877 & 1,97 & 7,34 & -977427 & -819980 \\
\hline \multicolumn{2}{|c|}{ Plain vanilla call opce } & 2219247 & 501566 & 2692960 & $-1,04$ & $-0,28$ & 193010 & 340811 \\
\hline \multirow{4}{*}{$\begin{array}{c}\text { Bariérové } \\
\text { opce }\end{array}$} & down-and-in & 3278017 & 4015657 & 2782617 & 3,00 & 13,95 & -219400 & -73323 \\
\hline & down-and-out & 2724433 & 3136642 & 2803963 & 4,92 & 42,41 & -98543 & 47534 \\
\hline & up-and-in & 3712593 & 4244204 & 2980352 & 3,28 & 17,05 & -26065 & 120012 \\
\hline & up-and-out & 2289663 & 2415283 & 2610434 & 2,88 & 14,01 & -98543 & -145995 \\
\hline
\end{tabular}

Z tabulky 3 je patrné, že k nejméně rizikovým strategiím patří krytá pozice se zajištěním na rok, nebot' směrodatná odchylka vyjadřující riziko je nulová. Medián představuje nejvyšší prostřední hodnotu ze všech získaných efektů. Mediánem rozumíme, že s 50\% pravděpodobností bude efekt vyšší resp. nižší než jeho naměřená hodnota. Nevýhodou tohoto zajišt'ovacího instrumentu je nemožnost dosahování zisku.

Pasivní strategie $\mathrm{s}$ týdenním zajištěním patří $\mathrm{k}$ méně rizikovým. Při porovnání střední hodnoty, reprezentující výnos, s ostatními zajištovacími nástroji, je patrné, že tato strategie nepatří $\mathrm{k}$ těm nejvýnosnějším. Šikmost dosahuje kladné hodnoty, a tudíž veličiny zobrazené v grafu hustoty rozdělení pravděpodobnosti jsou nachýlené doprava. To vypovídá o tom, že většina hodnot leží nad průměrem. Špičatost má kladnou hodnotu, a tedy dochází k špičatějšímu rozdělení pravděpodobnosti. 
Pasivní strategie s měsíčním zajištěním dosahuje také vysokých hodnot u výnosu. U mediánu jsme získali druhou největší hodnotu oproti ostatním derivátům. Šikmost i špičatost nabývá pozitivních výsledků, což je příznivé pro finanční veličiny. Při hodnocení rizika ztráty na hladině pravděpodobnosti $(10 \%, 90 \%)$ nabývá měsíční pasivní strategie nejhorších hodnot oproti ostatním.

Forwardový kontrakt patří ke strategiím s nižším rizikem. Z hlediska výnosu se řadí $\mathrm{k}$ méně výnosnějším zajišt'ovacím nástrojům. Medián má $v$ našem případě nejmenší hodnotu ze všech. Z pohledu šikmosti, jsou veličiny asymetricky rozloženy kolem středu naměřených hodnot s vychýlením na pravou stranu. Špičatost má kladnou hodnotu a rozdělení je tedy špičatější. Podle kritéria VaR s $(10 \%, 90 \%)$ hladinou pravděpodobnosti patří forward mezi strategie s lepší hodnotou.

Druhou nejméně rizikovou strategií je plain vanilla call opce. Je jedinou ze strategií, která má záporné hodnoty u šikmosti a špičatosti. Z pohledu šikmosti lze říci, že jde o asymetrické rozložení veličin nakloněné na levou stranu. U špičatosti je rozdělení pravděpodobnosti mírně plošší než u ostatních strategií.

U bariérových opcí ze zjištěných hodnot je jednoznačně zřejmé, že patří k nejvíce rizikovým strategiím, ale $\mathrm{z}$ hlediska střední hodnoty se řadí $\mathrm{k}$ těm nejvýnosnějším. Nejvyšší stř̌ední hodnoty dosahuje up-and-in call opce. Naopak nejnižší střední hodnotu spolu s mediánem má opce up-and-out. Opce down-and-out má vysoké hodnoty u šikmosti a špičatosti oproti ostatním hedgingovým instrumentům. Z hlediska VaR pro $1 \%, 5 \%$ a $10 \%$ dosahují opce down-and-up a up-and-out lepších hodnot než down-and-out a up-and-in.

Při rozhodování je pro jednotlivé subjekty stěžejní zhodnocení výnosu a rizika, zpravidla je požadován co největší výnos a co nejmenší riziko. Snahou je mezi nimi najít takový poměr, který neumožní zvýšit jeden parametr na úkor druhého. To znamená, že subjekty při vyšším výnosu musí podstoupit větší riziko a naopak.

Nejméně rizikovou strategií je krytá pozice. K méně rizikovým strategiím patří call opce, týdenní pasivní zajištění a forward. Když porovnáme tyto strategie mezi sebou, můžeme říci, že je vhodnější z hlediska výnosu zvolit zajištění pomocí call opce nebo týdenní pasivní zajištění.

Měsíční pasivní zajištění už je rizikovější strategií a $\mathrm{k}$ těm nejrizikovějším zajišt’ovacím instrumentům patří bariérové opce, především up-and-in, která dosahuje nevyššího rizika a zároveň i výnosu.

\section{Závěr}

Rozhodování o strategiích a koncepci zajištění finančního rizika je nezbytnou součástí strategického řízení každé společnosti. V tomto článku byla pozornost upřena na, dle našeho názoru velmi zajímavý, případ zajišsění komoditního rizika firmy působící v plynárenství.

Není snadné určit, která z porovnávaných strategií je obecně nejvýhodnější, jelikož s vyšším výnosem je spojeno vyšší riziko. Každý subjekt, každá firma, i investor do ní je ochoten postoupit různou úroveň rizika. Podle vztahu k riziku lze rozdělit subjekty do tř́ skupin, a to $\mathrm{s}$ averzí $\mathrm{k}$ riziku, s neutrálním postojem $\mathrm{k}$ riziku a se sklonem $\mathrm{k}$ riziku 
Společnost, v rámci jejíhož managementu či mezi majiteli převládají subjekty s velkou averzí k riziku, upřednostní nulové riziko, a proto využije krytou pozici. Za méně rizikové strategie můžeme považovat call opci. $\mathrm{V}$ případě subjektů se sklonem $\mathrm{k}$ riziku je vhodné zvolit jednu $\mathrm{z}$ variant bariérových opcí (down-and-in, down-and-out, up-and-in, up-and-out).

\section{Poděkování}

Tento článek vznikl v rámci projektu SGS SP2011/7 na VŠB-TU Ostrava a v rámci projektu Centrum excelence IT4Innovations, reg. č. CZ.1.05/1.1.00/02.0070 podporovaného Operačním programem Výzkum a vývoj pro inovace, financovaného ze strukturálních fondů EU a ze státního rozpočtu ČR.

\section{Literatura}

[1] BLANCO, C., SORONOW, D. Mean Reverting Processes - Energy Price Processes Used For Derivatives Pricing and Risk Management. Commodities New, June 2001, vol. 15, no. 2, s. 68-72.

[2] GEMAN, H. Commodities and Commodity Derivatives: Modeling and Pricing for Agriculturals, Metals and Energy. 1st Edition. Chichester, UK: Wiley, 2005. 416 p. ISBN 978-0-470-01218-5.

[3] HAUG. E. G. Derivatives Models on Models. 1st Edition. Chichester, UK: Wiley, 2007. 384 p. ISBN 978-0-470-01322-9.

[4] HAUG. E. G. The complete guide to Option Pricing Formulas. 2nd Revised Edition. McGrawHill, 2006. 536 p. ISBN 0-07-138997-0.

[5] HULL, J. C. Option, Futures and other Derivatives. 8th edition. Upper Saddle River, NS: Prentice Hall, 2010. 822 p. ISBN 0-13-216496-5.

[6] OVERDAHL, J., KOLB R. W. Futures, Options, and Swaps. 5th Revised Edition. Blackwell, 2007. 840 p. ISBN 9781405150491.

[7] SCHOFIELD, C. N. Commodity Derivatives: Markets and Applications. Chichester, UK: Wiley, 2007. 336 p. ISBN 978-0-470-01910-8.

[8] SCHAEFFER, P. V. Commodity Modeling and Pricing: Methods for Analyzing Resource Market Behavior. Chichester, UK: Wiley, 2008. 298 p. ISBN 978-0-470-31723-5.

[9] TICHÝ, T. Posouzení metody částečného hedgingu na případu řízení měnového rizika nefinanční instituce. Ekonomická revue - Central European Review of Economic, 2009, roč. 12, č. 2, s. 6982, ISSN 1212-3951.

[10] TICHÝ, T. Simulace Monte Carlo ve Financích: Aplikace při ocenění jednoduchých opcí. 6. vyd. Ostrava: VŠB-TU Ostrava (Series on Advanced Economic Issues), 2010. 216 s. ISBN 978-80248-2352-2.

[11] TICHÝ, T. Finanční deriváty, Typologie finančních derivátů, Podkladové procesy, Oceňovací modely. 1 vyd. VŠB - TU Ostrava, 2006. 162 s. ISBN 80-248-1180-4.

[12] ZMEŠKKAL, Z. Př́istupy k eliminaci finančních rizik na bázi finančních hedgingových strategií. Finance a úvěr - Czech Journal of Economics and Finance, 2004, roč. 54, č. 1-2, s. 50-63.

[13] ZMEŠKAL, Z., ČULÍK, M., TICHÝ, T. Finanční rozhodování za rizika: sbírka řššených př́kladů. 3 vyd. VŠB - TU Ostrava, 2011. 188 s. ISBN 978-80-248-2505-2.

Klasifikace JEL: G21, G22

\section{Denisa Vrebová, Markéta Jarotková}

Ekonomická fakulta

Vysoká škola báňská - Technická univerzita Ostrava

Katedra Financí

Sokolská třída 33, 70121 Ostrava 1

marketa.jarotkova@gmail.com 